\title{
SISTEM PENDUKUNG KEPUTUSAN SELEKSI CALON PENDIDIK MENGGUNAKAN METODE ANALYTICAL HIERARCHY PROCESS (AHP) BERBASIS WEB (STUDI KASUS: PAUD/TK TANWIRUL QULUB KABUPATEN PAMEKASAN)
}

\author{
Muhammad Nauval Hafidzi ${ }^{1}$, Nurudin Santoso ${ }^{2}$ \\ Program Studi Teknik Informatika, Jurusan Teknologi Informasi, Politeknik Negeri Malang. \\ Email: ${ }^{n}$ nauval.hafidzi@gmail.com,ㄲurudin@polinema.ac.id
}

\begin{abstract}
Abstrak
Sebuah sistem pendukung dibutuhkan oleh lembaga pendidikan, PAUD/TK Tanwirul Qulub untuk menentukan pendidik yang akan mengajar di lembaga tersebut. Sistem pendukung keputusan seleksi calon pendidik merupakan suatu sistem yang dapat membantu meningkatkan efektivitas dan efisiensi tim penyeleksi, meningkatkan kecepatan dan validitas pengambilan keputusan yang berkaitan dengan kegiatan operasional, dan meningkatkan kualitas akan calon pendidik. Metode yang digunakan dalam sistem pendukung ini adalah metode Analytical Hierarchy Process (AHP). Sebuah kerangka untuk mengambil keputusan dengan efektif terhadap persoalan yang kompleks dengan menyederhanakan dan mempercepat proses pengambilan keputusan. Proses yang dilakukan oleh metode ini adalah dengan menyeleksi, memilih serta menghitung kriteria calon pendidik. Dari hasil pengujian yang berupa uji coba fungsional dan uji coba akurasi hasil analisa, dapat ditemukan bahwa hasil pengujian yang dihasilkan oleh microsoft office excel dan sistem yang diuji, menunjukkan hasil yang tidak sama dikarenakan terjadi proses pembulatan dari beberapa kolom pada hasil penghitungan di microsoft excel ke dalam sistem yang telah diimplementasikan ke dalam bahasa pemrograman web PHP. Sehingga, dengan menggunakan sistem metode ini bisa membantu PAUD/TK Tanwirul Qulub dalam menentukan calon pendidik mereka.
\end{abstract}

Kata kunci: Sistem Pendukung Keputusan, Seleksi Calon Pendidik, Analytical Hierarchy Process (AHP)..

\section{Pendahuluan}

Pendidikan Anak Usia Dini (PAUD) adalah jenjang pendidikan sebelum memulai jenjang pendidikan dasar. Merupakan suatu upaya pembinaan yang ditujukan bagi anak sejak lahir sampai dengan usia enam tahun yang dilakukan melalui pemberian rangsangan pendidikan untuk membantu pertumbuhan dan perkembangan jasmani dan rohani agar anak memiliki kesiapan dalam memasuki pendidikan lebih lanjut, yang diselenggarakan pada jalur formal, nonformal, dan informal.

PAUD/TK Tanwirul Qulub adalah suatu lembaga sekolah yang masih baru dibawah naungan Yayasan Al-Ghazali, dan bediri sejak tahun 2011. Walaupun PAUD/TK Tanwiurl Qulub tidak pernah memperoleh fasilitas apapun dari yayasan induknya, sudah bisa dan dapat melakukan kegiatan operasional PAUD/TK sejak tahun 2011 secara mandiri dan telah mampu mencetak peserta didik yang berkualitas. Kualitas pendidikan anak usia dini sangat mempengaruhi keberhasilan peserta didik. Dan kualitas pendidikan usia dini tidak terlepas dari pendidik yang memberikan pendidikan dan pengajaran yang berkualitas.

Salah satu tugas pokok sekolah adalah menentukan kualitas pendidik dengan merekrut calon-calon pendidik yang akan mengabdi di sekolah tersebut.

Berdasarkan banyaknya tahapan dan kriteria, maka tim penyeleksi semakin banyak melakukan nilai penyeleksian. Dan pada penilaian tersebut juga dapat terjadi ketidakakuratan tim penyeleksi terhadap penilaian yang dilakukan. Supaya dapat mengatasi kesulitan dalam kegiatan seleksi pada calon pendidik dan untuk menghindari kesalahan dalam pengambilan keputusan yang akan ditentukan, maka PAUD/TK Tawirul Qulub membutuhkan suatu sistem pendukung keputusan dengan salah satu metode AHP (Analytical Hierarchy Process) yang terstruktur dan sistematis. Sehingga dapat mempermudah penyeleksian calon pendidik pada setiap tahap yag akan dilakukannya.

\section{Tinjauan Pustaka}

\subsection{Sistem Pendukung Keputusan}

Sistem Pendukung Keputusan (SPK) atau Decision Support System (DSS) adalah sebuah sistem yang mampu memberikan kemampuan pemecahan masalah maupun kemampuan pengkomunikasian untuk masalah dengan kondisi semi terstruktur dan tak terstruktur. Sistem ini digunakan untuk membantu pengambilan keputusan dalam situasi semi terstruktur 
dan situasi yang tidak terstruktur, dimana tak seorangpun tahu secara pasti bagaimana keputusan seharusnya dibuat (Turban, 2001).

Menutrut Alter (2002), DSS merupakan sistem informasi, pemodelan, dan pemanipulasian data. Sistem itu digunakan untuk membantu pengambilan keputusan dalam situasi yang semi terstruktur dan situasi yang tidak terstruktur, dimana tak seorangpun tahu secara pasti bagaimana keputusan seharusnya dibuat.

Dari definisi diatas dapat disimpulkan bahwa Sistem Pendukung Keputusan adalah suatu sistem yang dapat membantu mengambil sebuah keputusan yang bertujuan untuk memberikan prediksi dalam situasi terstruktur maupun tidak terstruktur.

\subsection{Metode Analytical Hierarchy Process (AHP)}

Metode AHP dikembangkan oleh Thomas L. Saaty, seorang dari Wharton School of Business pada tahun 70-an. Metode ini adalah sebuah kerangka untuk mengambil keputusan dengan efektif atas persoalan yang kompleks dengan menyeder-hanakan dan mempercepat proses pengambilan keputusan dengan memecahkan persoalan tersebut kedalam bagian-bagiannya, menata bagian atau variabel dalam suatu susunan hirarki, memberi nilai numerik pada pertimbangan subjektif tentang pentingnya tiap variabel dan mensintesis berbagai pertimbangan ini untuk menetapkan variabel yang mana yang memiliki prioritas paling tinggi dan bertindak untuk mempengaruhi hasil pada situasi tersebut. Dalam menyelesaikan permasalahan dengan AHP ada beberapa prinsip yang harus dipahami diantaranya adalah sebagai berikut (Kusrini, 2007:133):

a. Membuat hierarki

Sistem yang kompleks bisa dipahami dengann memecahnya menjadi elemen-elemen pendukung, menyusun elemen secara hierarki, dan menggabung kannya.

b. Penilaian kriteria dan alternatif

Kriteria dan alternatif dilakukan dengann perbandingan berpasangan Menurut Saaty (1988), untuk berbagai persoalan skala 1 sampai 9 adalah skala terbaik untuk mengekspresikan pendapat. Nilai dan definisi pendapat kualitatif dari skala perbandi ngan Saaty bisa diukur menggunakan tabel analisis seperti pada Tabel 1.

c. Menentukan prioritas

Untuk setiap kriteria dan alterntif, perlu dilakukan perbandingan berpasangan. Nilai-nilai perbandingan relatif dari seuruh alternatif kriteria bisa disesuaikan dengann judgement yang telah ditentukan untuk menghasilkan bobot dan prioritas. Bobot dan prioritas dihitung dengann memanipulasi matriks atau melalui penyelesaian persamaan matematika.

d. Konsistensi logis

Konsistensi memiliki dua makna. Pertama objekobjek yang serupa bisa dikelompokkan sesuai dengann keseragaman dan relevansi. Kedua, menyangkut tingkat hubungan antar objek yang didasarkan pada kriteria tertentu.

Tabel 1 Skala Penilaian Perbandingan Berpasangan

\begin{tabular}{|c|c|}
\hline $\begin{array}{c}\text { Intensitas } \\
\text { Kepentingan }\end{array}$ & Keterangan \\
\hline 1 & Kedua elemen sama penting \\
\hline 3 & $\begin{array}{l}\text { Elemen yang satu sedikit lebih } \\
\text { penting dari pada elemen lainnya }\end{array}$ \\
\hline 5 & $\begin{array}{l}\text { Elemen yang satu lebih penting } \\
\text { dari pada elemen lainnya }\end{array}$ \\
\hline 7 & $\begin{array}{l}\text { Satu elemen jelas lebih mutlak } \\
\text { penting dari pada elemen lainnya }\end{array}$ \\
\hline 9 & $\begin{array}{l}\text { Satu elemen mutlak penting dari } \\
\text { pada elemen lainnya }\end{array}$ \\
\hline $2,4,6.8$ & $\begin{array}{l}\text { Nilai antara dua nilai } \\
\text { pertimbangan yang berdekatan }\end{array}$ \\
\hline Kebalikan & $\begin{array}{l}\text { Jika aktivitas i mendapat satu } \\
\text { angka dibandingkan dengan } \\
\text { aktivitas } \mathrm{j} \text {, maka } \mathrm{j} \text { memiliki nilai } \\
\text { kebalikannya dibandingkan } \\
\text { dengan } \mathrm{i}\end{array}$ \\
\hline
\end{tabular}

Sumber: *Thomas L.Saaty, Decission Making for Leader, 1986

Pada dasarnya, prosedur atau langkah-langkah dalam metode AHP meliputi (Kusrini, 2007:135):

a. Mendefinisikan masalah dan menentukan solusi yang diinginkan, setelah itu menyusun hirarki dari permasalahan yang dihadapi. Penyusunan hirarki adalah dengan menetapkan tujuan yang merupakan sasaran sistem secara keseluruhan pada level teratas. b. Menentukan prioritas elemen

Langkah pertama untuk menentukan prioritas elemen adalah membuat perbandingan pasangan, yaitu membandingkan elemen secara berpasangan sesuai kriteria yang diberikan.

Matriks perbandingan berpasangan diisi mengguna kan bilangan untuk mempresentasikan kepentingan relatif dari suatu elemen terhadap elemen yang lainnya.

c. Sintesis pertimbangan-pertimbangan terhadap perbandingan berpasangan disintensis untuk memperoleh keseluruhan prioritas. Hal-hal yang dilakukan langkah ini adalah: (1) Menjumlahkan nilai-nilai dari setiap kolom matriks. (2) Membagi setiap nilai dari kolom pada matriks. (3) Menjumlahkan nilai-nilai dari setiap baris dan membaginya dengan jumlah elemen untuk mendapatkan nilai rata-rata.

d. Mengukur Konsistensi Dalam pembuatan keputusan, penting untuk mengetahui seberapa baik konsistensi yang ada karena kita tidak menginginkan keputusan berdasarkan pertimbangan dengan konsistensi yang rendah. Hal-hal yang dilakukan untuk langkah ini adalah: (1) Kalikan setiap nilai pada kolom pertama dengan prioritas relatif elemen pertama, nilai pada kolom kedua dengan prioritas relatif elemen kedua, dan seterusnya. (2) Jumlahkan setiap baris. (3) Hasil dari penjumlahan baris dibagi 
dengan elemen prioritas relatif yang bersangkutan. (4) Jumlahkan hasil bagi di atas dengan banyaknya elemen yang ada, hasilnya disebut $\lambda$ maks.

e. Hitung Consistensy Index (CI) dengan rumus:

$\mathrm{CI}=(\lambda$ maks- $\mathrm{n}) / \mathrm{n}-1$

dimana $\mathrm{n}=$ banyaknya elemen

f. Hitung rasio konsistensi/ Consistensy Ratio (CR) dengan rumus:

$$
\mathrm{CR}=\mathrm{CI} / \mathrm{IR}
$$

dimana $\quad \mathrm{CR}=$ Consistensy Ratio

$\mathrm{CI}=$ Consistensy Index

$\mathrm{IR}=$ Indeks Random Consistensy

g. Memeriksa konsistensi hirarki. Jika nilainya lebih dari 10\%, maka penilaian data judgment harus diperbaiki. Namun jika rasio konsistensi (CI/IR) kurang atau sama dengan 0,1 maka hasil penghitungan bisa dinyatakan benar. Daftar indeks random konsistensi (IR) bisa dilihat pada Tabel 2 .

Tabel 2 Nilai Indeks Random

\begin{tabular}{|c|c|}
\hline \multicolumn{2}{|c|}{ Tabel RI } \\
\hline $\mathbf{n}$ & $\mathbf{R I}$ \\
\hline 1 & 0 \\
\hline 2 & 0 \\
\hline 3 & 0,58 \\
\hline 4 & 0,9 \\
\hline 5 & 1,12 \\
\hline 6 & 1,24 \\
\hline 7 & 1,32 \\
\hline 8 & 1,41 \\
\hline 9 & 1,45 \\
\hline 10 & 1,49 \\
\hline 11 & 1,51 \\
\hline 12 & 1,48 \\
\hline 13 & 1,56 \\
\hline 14 & 1,57 \\
\hline 15 & 1,59 \\
\hline
\end{tabular}

\section{Perancangan}

\subsection{Use Case}

Berikut adalah hasil perancangan diagram use case yang diharapkan dari sebuah sistem dan juga dapat membantu untuk menyusun requirements sebuah sistem. Diagram use case dapat dilihat sebagai berikut.

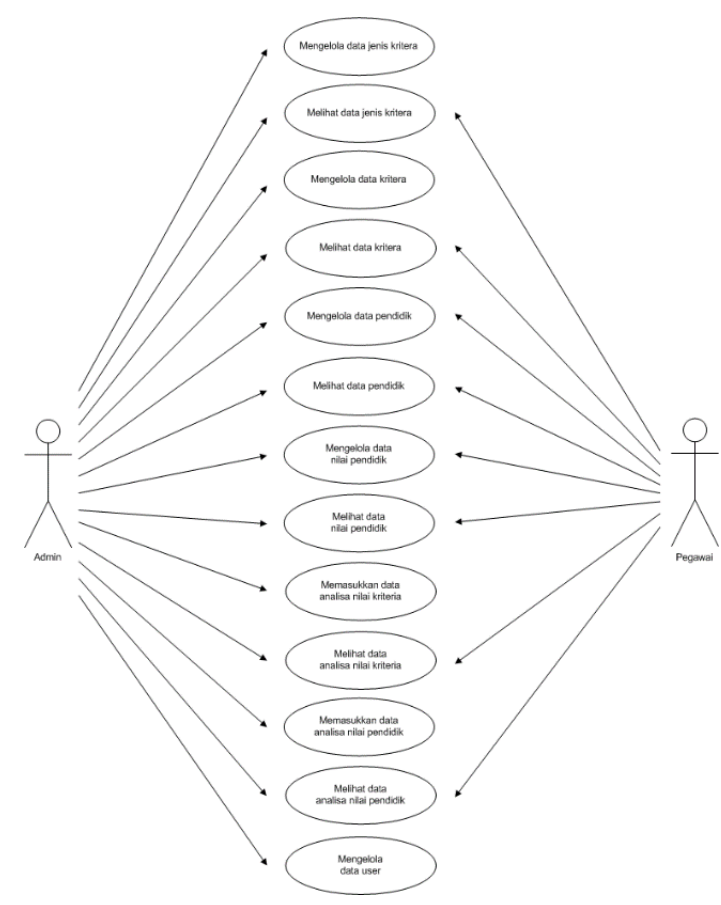

Gambar 1 Use Case Diagram

3.2 EntityRelationship Diagram

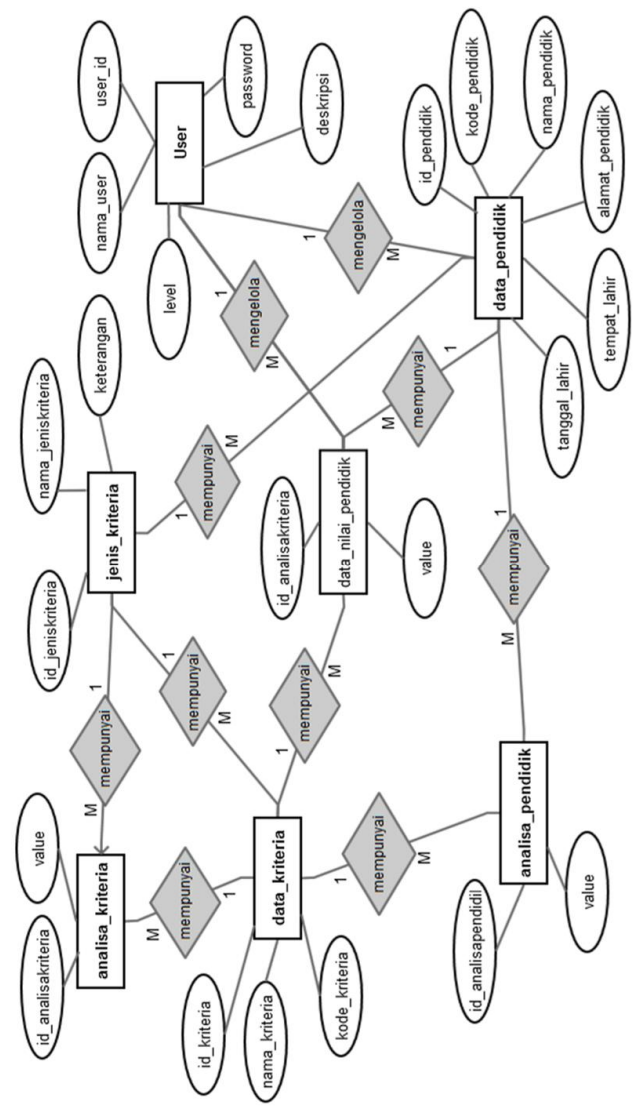

Gambar 2 Entity Relationship Diagram 


\section{Hasil Pengujian}

Berikut ini adalah hasil pengujian yang telah diimplementasikan ke dalam sistem.

\subsection{Pengujian Kriteria}

a. Membuat matriks perbandingan berpasangan. Terlebih dahulu melakukan penilaian perbandingan antara satu kriteria dengan kriteria yang lain.

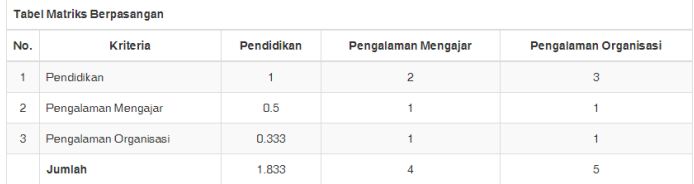

Gambar 3 Matriks Perbandingan Berpasangan

Angka 1 pada kolom pendidikan baris pendidikan menggambarkan tingkat kepentingan yang sama antara pendidikan dengan pendidikan, sedangkan angka 2 pada kolom pengalaman mengajar baris pendidikan menunjukkan pendidikan mendekati sedikit lebih penting dibandingkan dengan pengalaman mengajar. Angkat 0,5 pada kolom pendidikan baris pengalaman mengajar merupakan hasil penghitungan 1 /nilai pada kolom pengalaman mengajar baris pendidikan (2). Angka-angka lainnya diperoleh dengan cara yang sama. Nilai 1,833 pada kolom pendidikan diperoleh dari hasil penjumlahan ke bawah pada masing-masing kolom.

b. Membuat matriks nilai kriteria

Matriks nilai kriteria disebut juga eigen vector ternormalisasi. Matriks ini diperoleh dengan rumus sebagai berikut.

Nilai baris kolom baru $=\frac{\text { Nilai baris kolom lama }}{\text { Jumlah masing kolom lama }}$

Hasil dari penghitungan dari rumus diatas, dapat dilihat pada gambar berikut

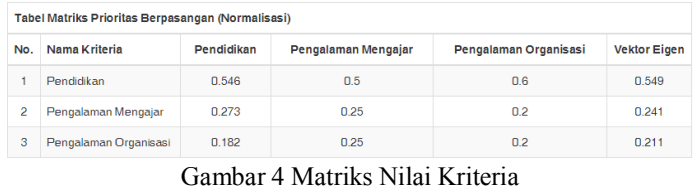

Nilai 0,546 pada kolom pendidikan baris pendidikan Gambar 4 diperoleh dari nilai kolom pendidikan baris pendidikan Gambar 3 dibagi jumlah kolom pendidikan Gambar 3. Nilai 0,549 pada kolom vector eigen diperloleh dari hasil rata-rata pada setiap barisnya.

c. Membuat matriks penjumlahan setiap baris

Matriks ini diperoleh dengan mengalikan nilai eigen vector pada Gambar 4 dengan matriks perbandingan berpsangan Gambar 3. Hasil penghitungan disajikan dalam Gambar 5.

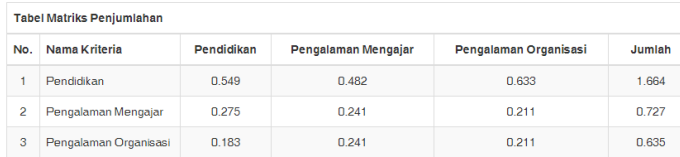

Gambar 5 Matriks Penjumlahan

Nilai 0,549 pada baris pendidikan kolom pendidikan Gambar 5 diperoleh dari dari eigen vector baris pendidikan pada Gambar $4(0,546)$ dikalikan dengan nilai baris pendidikan kolom pendidikan Gambar 3 .
Nilai 0,275 pada baris pengalaman mengajar kolom pendidikan Gambar 5 diperoleh dari eigen vector baris pengalaman mengajar pada Gambar $4(0,241)$ dikalikan nilai baris pengalaman mengajar kolom pendidikan pada Gambar $3(0,5)$. Kolom jumlah pada Gambar 5 diperoleh dengan menjumlahkan nilai pada masing-masing baris pada tabel tersebut

d. Menghitung rasio konsistensi

Penghitungan ini digunakan untuk mengetahui apakah nilai rasio konsistensi $(\mathrm{CR})<=0,1$. Jika nilai CR lebih besar dari 0,1 , maka matriks perbandingan harus diperbaiki.

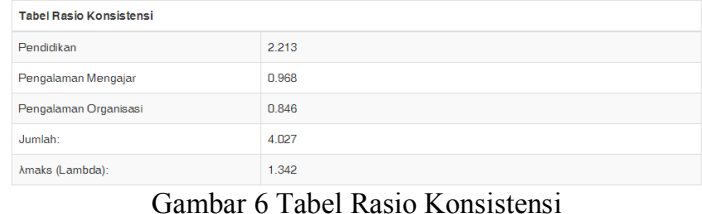

Nilai 2,213 pada baris pendidikan diperoleh dari mengalikan antara kolom jumlah pada Gambar 5 dan kolom vector eigen Gambar 4. sedangkan baris jumlah diperoleh dari hasil penjumlahan ke bawah. Selanjutnya, hasil penghitungan dari Gambar 6 diperoleh nilai-nilai sebagai berikut.

$\lambda$ maks $=$ jumlah $/ \mathrm{n}(\mathrm{n}=$ jumlah kriteria $)$

Kemudian menghitung Consistency Index dengan rumus sebagai berikut.

Consistency Index $=(\lambda$ maks $-n) /(n-1)$

Dan yang terakhir adalah menghitung Rasio Konsistensi (CR) dengan rumus sebagai berikut.

Consistency Ratio $=$ CI $/$ Indeks Random Consistensy

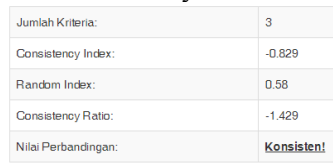

Gambar 7 Pengecekan Konsistensi

Oleh karena Consistency Ratio (CR) kurang dari 0,1 , maka rasio konsistensi dari penghitungan diatas dapat diterima.

\subsection{Pengujian Calon Pendidik Kriteria} Pendidikan

a. Membuat matriks perbandingan berpasangan.

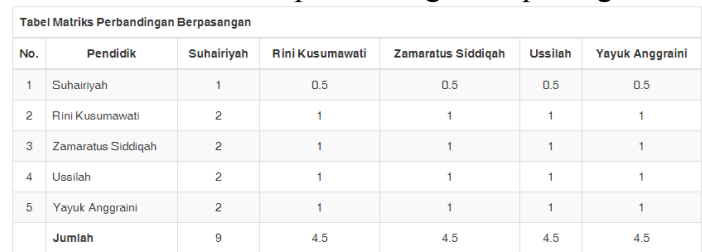

Gambar 8 Matriks Perbandingan Berpasangan

b. Membuat matriks nilai pendidik kriteria pendidikan

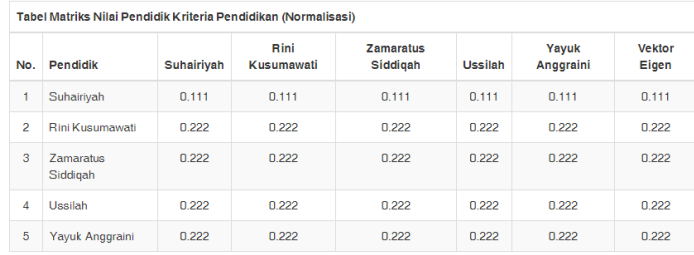

Gambar 9 Matriks Nilai Pendidik Kriteria Pendidikan 


\subsection{Pengujian Calon Pendidik Kriteria Pengalaman Mengajar}

a. Membuat matriks perbandingan berpasangan.

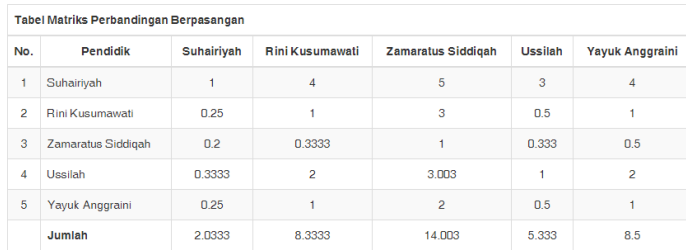

Gambar 10 Matriks Perbandingan Berpasangan b. Membuat matriks nilai pendidik kriteria pengalaman mengajar

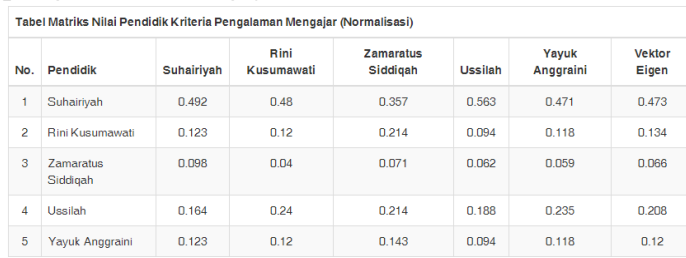

Gambar 11 Matriks Nilai Pendidik Kriteria Pengalaman Mengajar

4.4 Pengujian Calon Pendidik Kriteria Pengalaman Organisasi

a. Membuat matriks perbandingan berpasangan.

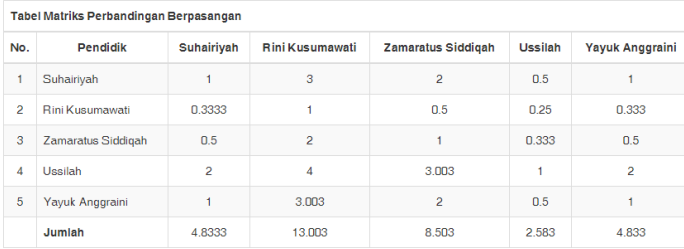

Gambar 12 Matriks Perbandingan Berpasangan

b. Membuat matriks nilai pendidik kriteria pengalaman organisasi

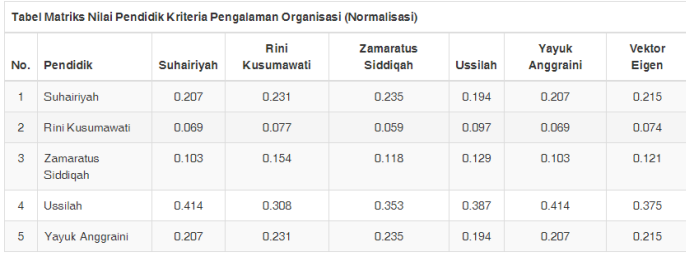

Gambar 13 Matriks Nilai Pendidik Kriteria Pengalaman Organisasi

\subsection{Pengujian Hasil Akhir}

Setelah semua pengujian kriteria dan calon pendidik pada masing-masing kriteria telah dilakukan pengujian, yang terakhir yaitu pengujian hasil akhir.

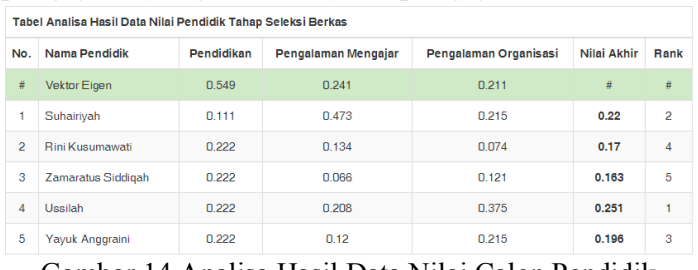

Gambar 14 Analisa Hasil Data Nilai Calon Pendidik
Nilai 0,549 pada baris vector eigen kolom pendidikan, diperoleh dari vector eigen Gambar 5. Nilai 0,111 pada kolom pendidikan diperoleh dari vector eigen pada Gambar 9. Nilai 0,22 pada kolom nilai akhir diperoleh dari eigen vector kriteria dikali eigen vector calon pendidik, kemudian ditambahkan dengan hasil perkalian vector eigen kriteria dan vector eigen calon pendidik pada baris selanjutnya. Contoh pada baris calon pendidik Suhairiyah, yaitu $(0,111 \times 0,549)+(0,473 \times 0,241)+(0,215 \times 0,2111)=0,22$. Nilai pada kolom rank diperoleh dari kolom nilai akhir pada baris calon pendidik yang telah diranking secara keseluruhan.

\section{Kesimpulan}

Berdasarkan pembahasan dari bab-bab sebelumnya, maka dapat ditarik kesimpulan, yaitu sistem yang dibangun dapat membantu tim penyeleksi dalam merekrut seorang pendidik yang dibutuhkan oleh ketua yayasan PAUD/TK Tanwirul Qulub Pamekasan.

Kemudian sistem pendukung keputusan dengan model AHP memberikan manfaat kemudahan/ banyaknya alternatif pilihan keputusan dalam seleksi calon pendidik.

Serta penulis dapat mengetahui kelemahan sistem lama dan keunggulan sistem baru. Sistem baru lebih banyak memberikan alternatif pilihan keputusan (fleksibel) sesuai dengan kriteria yang diinginkan dalam seleksi pegawai.

\section{Daftar Pustaka}

Asja, Mawardi. Pengantar Penggunaan AHP (Analytical Hierarchy Process) dalam Pengambilan Keputusan. 25 Januari 2015. http://mawardisyana.blogspot.com/2013/04/pen gantar-penggunaan-ahp-analytical.html

Hartoto. Pendidik dan Peserta Didik. 25 Januari 2015.

https://fatamorghana.wordpress.com/2009/04/15 /pendidik-dan-peserta-didik/

Haryanto. Pentingnya Pendidikan Bagi Kehidupan. 25 Januari 2015.

http://belajarpsikologi.com/pentingnya-pendidikanbagi-kehidupan/

HM, Jugiyanto. 2003. Sistem Teknologi Informasi. Yogyakarta: ANDI.

Kusrini. 2007. Konsep dan Aplikasi Sistem Pendukung Keputusan.Yogyakarta: ANDI.

Rapi, Mujahidah. Konsep Pendidikan Anak Usia Dini. 25 Januari 2015.

http://sulsel.kemenag.go.id/file/file/ArtikelTulisan/o klv1383112871.pdf

Riadi, Muchlisin. Pengertian Sistem Pendukung Keputusan. $25 \quad$ Januari 2015. http://www.kajianpustaka.com/2013/09/sistempendukung-keputusan-spk.html 